\title{
Influence of Plant Growth Regulators (PGRs) and Planting Method on Growth and Yield in Oil Pumpkin (Cucurbitapepo var. styriaca)
}

\author{
Shirzad SURE*, Hosein AROOIE, Majid AZIZI \\ Ferdowsi University of Mashhad, Department of Horticultural Science, Mashhad, Iran; Shirzad_sure@yahoo.com (*corresponding author)
}

\begin{abstract}
The effect of plant growth regulators IBA (indole butyric acid), GA (gibberellin) and ethylene (as ethephon) in two methods of planting was investigated (each method was considered as a separate experiment) on morphological characters and yield of medicinal pumpkin. The experiments were carried out in a factorial trial based on completely randomized block design, with four replicates. The treatments were combined with priming and spraying with the above PGRs. The first seed priming with control (water), IBA 100 ppm, $\mathrm{GA}_{3} 25 \mathrm{ppm}$ and ethephon $200 \mathrm{ppm}$, and when seedling developed to 4 leaf stage sprayed there with control (water), IBA 100 ppm, GA $25 \mathrm{ppm}$ and ethephon $200 \mathrm{ppm}$ for three times. In both planting methods, there were all of these treatments. The result showed that PGRs and planting method had significant effects on vegetative, flowering and yield characteristics including: leaf area \%DM plant, number of male and female flowers per plant, number of fruit/plant, fruits fresh weight, seeds length and width, number of seed per fruit, seed yield, \% seeds oil and oil yield. Hence spraying with $\mathrm{GA}_{3} 25 \mathrm{ppm}$ in four leaf stage at trellis method could be a suitable treatment for enhancing growth and yield of medicinal pumpkin.
\end{abstract}

Keywords: medicinal pumpkin, oil yield, plant growth regulator, planting method

\section{Introduction}

Research on crop seeds in the entire world indicated that seeds contain a high percentage of protein and especially oil that showed a suitable nutritional value of these crops. One of the valuable plants in the pharmaceutical industry in most developed countries is oil pumpkin (Cucurbita pepo var. styriaca) that belongs to Cucurbitaceae family. In recent years the use of oils crops, especially vegetables oil have been focused on (Bombardelli and Morazzoni, 1997). PGRs (GA and IBA and ethephon) play an important role in morphology and physiology of the plants. PGRs influence the plant growth and morphogenesis. They should be applied in optimal concentrations, stage of application, species specificity, seasons, etc. accurately. (Birader and Navalagatti, 2008). PGRs such as auxin and gibberellin include many aspects of plant growth and development. Also, they have important roles in many processes such as germination, seedling growth, product performance and yield and ripening (Al-Khassawneh et al., 2006). Seed priming with PGRs caused an increase in seed germination and seedling vigor (Chauhan $e t$ al., 2010; Jamil and Rha, 2007). In recent years, plant growth, flowering and yield have been manipulated with the help of growth regulating substances. Some PGRs have important effect on sex expression in various cucurbitaceous crops. Also, by decreasing or increasing the male or female flowers, it causes change in yield (Hilli et al., 2005). PGRs are chemical materials that are used in low concentration change the growth of plant usually by stimulating part of the natural growth regulatory system. Ethrel at $400 \mathrm{ppm}$ in four to six leaf stage significantly increased the number of female flowers per plant (35.23\%) and reduced the sex ratio (3.69) compared to control (19.8 and 224.5, respectively) in cucumber (Vadigeri et al., 2001). Ethephon at $100 \mathrm{ppm}$ enhanced the total yield of cucumber (Thappa et al., 2011) Trailing method plays very important role in growth and quality of Cucurbitaceae family crops. Sedghi et al. (2010) reported NAA increased the number of seed per fruit doubled and enhanced the seed yield significantly with compared to the control. Part et al. (2008) reported $\mathrm{GA}_{3}$ increased the growth characteristic and total flowering in jujube. Asrey et al. (2001) studied the effect of seed priming with $\mathrm{GA}_{3}$ on growth and fruiting in musk melon and reported that $\mathrm{GA}_{3}$ at $400 \mathrm{ppm}$ enhanced the yield significantly with compared to control. Ntui et al. (2007) showed that application of NAA at $100 \mathrm{ppm}$ increased the seed yield in pumpkin). Ethrel at $400 \mathrm{ppm}$ in four to six leaf stage significantly increased the number of female flowers per plant $(35.23 \%)$ and reduced the sex ratio (3.69) compared to control (19.8 and 224.5 respectively) in cucumber (Vadigeri et al., 2001). Ethrel at 300 and 500 ppm had little effect on 1000-seed weight and Seed germination was not influenced by ethrel in Cucurbita maxima (Korzeniewska and Niemirowiez, 1993). Gad et al. (1993) studied showed Ethrel at 225 or 300 ppm were very effective on summer squash sex expression and enhanced number of fruit per plant and total yields. Ethephon at $100 \mathrm{ppm}$ enhanced the total yield of cucumber (Thappa et al., 2011) Trailing method play very important role in 
102

growth and quality of Cucurbitaceae family crops. Since, when fruits are in contact with the ground, it is likely to decay and reduce the quality, under irrigation condition and during rainy season, the crop should be staked or trailed so that fruits will be prevented from direct contact with the soil. Higher productivity in trailing is due to increase in the photosynthesis sunlight by maximum number of leaves and higher number of side branches resulting in enhanced assimilation of carbohydrates caused to increase in yield. Singh et al. (1982) studied the trellis method on muskmelon and reduction in plant to plant spacing to 30 $\mathrm{cm}$ resulted in further increase in the fruit yield than the plants spreading on the ground. Hilli et al. (2009) studied the effect of trellis on yield of ridge gourd and reported that fruit yield and \%DM significantly increased compared to farming method (without staking). Due to the importance of this product and inadequate data on the effect of PGRs on growth and yield in medicinal pumpkin, the present investigation was aimed to find out suitable growth regulators for increasing the yield potential and also quality in medicinal pumpkin.

\section{Materials and methods}

To study the effect of PGRs on growth and yield on medicinal pumpkin (Cucurbita pepo var. styriaca, cv. 'Kaki') two experiments were conducted at Agricultural Research Station in Ferdowsi University of Mashhad, Mashhad Iran, during spring and summer 2011. The cultivar employed in this experiment was Kakai.

\section{Experiment 1}

This experiment was conducted in farming method (without staking) in four blocks (each block $88 \mathrm{~m}^{2}$ ) and there were sixteen plots in each block (each plots $5.5 \mathrm{~m}^{2}$ ) and in each plot there were 10 plants. Distance on the stack was $200 \mathrm{~cm}$ and spacing on the row was $40 \mathrm{~cm}$.

\section{Experiment 2}

This experiment was conducted to trellis method in four blocks (each block $35.2 \mathrm{~m}^{2}$ ) and there were sixteen plots in each block (each plots $2.2 \mathrm{~m}^{2}$ ) and in each plot, there were 10 plants. Distance on the stack was 50 centimeters and spacing on the row was 40 centimeters.

In both experiments, treatments were seed priming with PGRs [control (water), IBA (100 ppm), GA 3 (25 ppm) and ethephon $(200 \mathrm{ppm})] 20 \mathrm{~h}$, and then seeds sowed. After seedling developing on true four-leaf stage, seedlings were sprayed with PGRs [control (water), IBA
(100 ppm), $\mathrm{GA}_{3}(25 \mathrm{ppm})$ and ethephon (200 ppm)] for three times.

Each experiment had 16 treatments (in fact all treatments were combinations of priming and spray) witch are presented in Tab. 1.

In both experiments, after the soil analysis, fields were ploughed twice, first with disc plough in autumn and the second was manually done in spring. Farm manure at 30 t/ ha were applied in each plot separately at the time of final land preparation and $\mathrm{N}$ fertilizer $(75 \mathrm{~kg} / \mathrm{ha})$ was applied to road method in three stages (planting time, four-leaf stage and during flowering). Seed sowed in 10 May 2011 at $40 \mathrm{~cm}$ plant-to-plant distance. Surface irrigation was practiced at 4-7 days interval in summer when necessary and weeding was handy. Number of male and female flower, number of node to first male and female flower, fresh and dry weight of leaf, stem and root were measured thrice at flowering stage. Average numbers of fruits per plant, number of seed in fruit, mean of fruit weight, seed oil percentage were counted.

\section{Statistical analysis}

The experiment was carried out in a factorial trial based on completely randomized design, with three replicates. ANOVA was run for the variables by SAS 9.2 software and the least Significant Difference (LSD) test was used to separate the means at $p<0.05$ and the charts were drowned in Excel 2010.

\section{Results and discussion}

\section{Experiment 1 (farming method)}

The result indicated that there were significant effects between all treatments on the growth and yield characteristics (Tab. 1).

\section{Morphological traits}

$\mathrm{GA}_{3}$ and IBA have significant effect on growth characteristics compared to control and ethephon. The highest leaf area $\left(418.57 \mathrm{~cm}^{2}\right)$ was recorded at $\mathrm{P}_{2} \mathrm{~S}_{3}$ (combined effect of priming with IBA and spraying with $\mathrm{GA}_{3}$ ) treatment. The highest DM\% of plant (14.31\%) was measured in $\mathrm{P}_{1} \mathrm{~S}_{3}$ (combined effect of priming with control and spraying with $\left.\mathrm{GA}_{3}\right)$. These results are in agreement with several investigators (Akter et al., 2007; Asrey et al., 2001, Emongor, 2007). This had proved that $\mathrm{GA}_{3}$ influences a range of developmental processing in stem elongation, germination, flowering, sex expression, enzyme induction

Tab. 1. Number of treatments applied on growth and yield on medicinal pumpkin (Cucurbita pepo var. styriaca, cv. 'Kaki')

\begin{tabular}{|c|c|c|c|c|c|c|c|c|c|c|c|c|c|c|c|c|}
\hline & 1 & 2 & 3 & 4 & 5 & 6 & 7 & 8 & 9 & 10 & 11 & 12 & 13 & 14 & 15 & 16 \\
\hline $\mathrm{P}$ & Con & Con & Con & Con & IBA & IBA & IBA & IBA & $\mathrm{GA}_{3}$ & $\mathrm{GA}_{3}$ & $\mathrm{GA}_{3}$ & $\mathrm{GA}_{3}$ & Eth & Eth & Eth & Eth \\
\hline$S$ & Con & IBA & $\mathrm{GA}_{3}$ & Eth & Con & IBA & GA & Eth & Con & IBA & $\mathrm{GA}_{3}$ & Eth & Con & IBA & $\mathrm{GA}_{3}$ & Eth \\
\hline & $\mathrm{P}_{1} \mathrm{~S}_{1}$ & $\mathrm{P}_{1} \mathrm{~S}_{2}$ & $\mathrm{P}_{1} \mathrm{~S}_{3}$ & $\mathrm{P}_{1} \mathrm{~S}_{4}$ & $\mathrm{P}_{2} \mathrm{~S}_{1}$ & $\mathrm{P}_{2} \mathrm{~S}_{2}$ & $\mathrm{P}_{2} \mathrm{~S}_{3}$ & $\mathrm{P}_{2} \mathrm{~S}_{4}$ & $\mathrm{P}_{3} \mathrm{~S}_{1}$ & $\mathrm{P}_{3} \mathrm{~S}_{2}$ & $\mathrm{P}_{3} \mathrm{~S}_{3}$ & $\mathrm{P}_{3} \mathrm{~S}_{4}$ & $\mathrm{P}_{4} \mathrm{~S}_{1}$ & $\mathrm{P}_{4} \mathrm{~S}_{1}$ & $\mathrm{P}_{4} \mathrm{~S}_{3}$ & $\mathrm{P}_{4} \mathrm{~S}_{4}$ \\
\hline
\end{tabular}

$\mathrm{P}=$ priming, $\mathrm{S}=$ spray, $\mathrm{Con}=$ control, Eth=ethephon 
and can improve the seedling vigor. Applications of PGRs such as $\mathrm{GA}_{3}$ have prompted the metabolic activities in plants due to enhancing vegetative growth. Plants which were treated with $\mathrm{GA}_{3}$ have a higher leaf area, and vegetative growth and can enhance the photosynthesis, and can be very effective on final yield.

\section{Floral traits}

The application of ethephon decreased the sex ratio (male/female). These results indicated that ethephon was more effective in female flower apparition. Spray ethephon enhanced the number of female flower and reduced male flower significantly, even in some vine no mail flower was observed. The number of male flowers was maximized in $\mathrm{GA}_{3}$ treatment (combined effect of priming with $\mathrm{GA}_{3}$ and spraying with $\mathrm{GA}_{3}$ ) this result was confirmed by Yamasaki et al. (2003) on cucumber, Brantley and Warren (1960) on muskmelon. The sex expression of medicinal pumpkin is determined by genetics as well as environment. The application of ethephon can have effects on sex ratio and increase the ultimate fruit yield/plant by increasing the number of pistillate flowers and fruit set percentage.

\section{Yield components}

Number of fruit/plant was affected by ethepon treatment (Tab. 2). Considering that normally medicinal pumpkin given one fruit/plant, ethephon with enhancing female flower increased the number of fruit/plant, and highest number of fruit (1.25) was obtained at $\mathrm{P}_{2} \mathrm{~S}_{4}$ (combined effect of priming with IBA and spraying with ethephon) this result was consistent with Vadigar et al. (2001) and Desai et al. (1994). The application of IBA and GA were more effective on fresh weight of fruit. Fresh weight of fruit was maximized by $\mathrm{P}_{2} \mathrm{~S}_{1}$ (combined effect of priming with IBA and spraying with control) (Gedam et al., 1998; Sidhu et al., 1981). Maximum of seed/fruits (325.43) was observed in $\mathrm{P}_{4} \mathrm{~S}_{2}$ (combined effect of priming with IBA and spraying with control). This result is consistent with Marbhal et al. (2005) and Dostogir et al. (2006). Thousand seed weight was affected by GA 3 and IBA treatment and had significant effect compared to the control. GA and IBA were more effective in seeds specifications; both seed length and width were maximized by IBA (combined effect of priming with control and spraying with IBA) to $(19.26 \mathrm{~mm})(9.71 \mathrm{~mm})$, respectively.

\section{Total seed yield $(\mathrm{kg} / \mathrm{ha})$, seed oil percent and total seed oil $\mathrm{kg} / \mathrm{ha}$}

The result indicated that the application of PGRs enhanced seed yield significantly compared to control (Fig. 1). The maximum total seed yield $(946.73 \mathrm{~kg} / \mathrm{ha})$ was found in $\mathrm{P}_{2} \mathrm{~S}_{4}$ (combined effect of priming with IBA and spraying with ethephon). Despite enough space to growth on the farming method, the $\mathrm{P}_{2} \mathrm{~S}_{4}$ treatment by maximizing the fruit number per plant increased yield $\mathrm{kg} / \mathrm{ha}$. This result is consistent with the results of (Birader and $\mathrm{Na}$ valagatti, 2008; Sedghi et al., 2010; Thappa et al., 2011; Vwioko and Ukpo Longe, 2009) in their study. The seed oil \% was directly affected by PGRs application, specially $\mathrm{GA}_{3}$. Both methods of the application of $\mathrm{GA}_{3}$ (priming and spray) have significant effect on oil $\%$ compared to the other treatment. Result indicated that foliar application of $\mathrm{P}_{2} \mathrm{~S}_{3}$ (combined effect of priming with IBA and spraying with $\mathrm{GA}_{3}$ ) treatment enhanced seed oils \% (38.08\%) significantly compared to the other treatment (Fig. 2), and oil yield to (346.51) maximized by $\mathrm{P}_{2} \mathrm{~S}_{4}$ (combined

Tab. 2. Effect of PGRs on growth and yield characteristics on (Cucurbita pepo var. styriaca cv. 'Kaki') in farming method

\begin{tabular}{|c|c|c|c|c|c|c|c|c|c|}
\hline Treatment & $\begin{array}{c}\text { Leaf area } \\
\mathrm{cm}^{2}\end{array}$ & $\begin{array}{c}\text { Sex ratio } \\
\text { male/female }\end{array}$ & $\begin{array}{l}\text { DM of } \\
\text { vine } \%\end{array}$ & $\begin{array}{c}\text { Number of } \\
\text { fruit per plant }\end{array}$ & $\begin{array}{l}\text { Fresh weight } \\
\text { of fruit }(\mathrm{kg})\end{array}$ & $\begin{array}{c}\text { Number of } \\
\text { seed per fruit }\end{array}$ & $\begin{array}{l}1000 \text { Seed } \\
\text { weight }(\mathrm{g})\end{array}$ & $\begin{array}{l}\text { Length of } \\
\text { seed }(\mathrm{mm})\end{array}$ & $\begin{array}{r}\text { Width of } \\
\text { seed }(\mathrm{mm})\end{array}$ \\
\hline $\mathrm{P}_{1} \mathrm{~S}_{1}$ & $346.65 \mathrm{~g}$ & $11 \mathrm{~b}$ & $13.05 j$ & $0.6 \mathrm{i}$ & $1.65 \mathrm{~g}$ & $275.11 \mathrm{~d}$ & $130.57 \mathrm{gh}$ & $17.15 \mathrm{jk}$ & $8.34 \mathrm{fg}$ \\
\hline $\mathrm{P}_{1} \mathrm{~S}_{2}$ & $402.68 \mathrm{~b}$ & $10.8 \mathrm{~b}$ & $14.08 \mathrm{~b}$ & $0.9 \mathrm{de}$ & $1.7 \mathrm{~g}$ & $228.07 \mathrm{~g}$ & $141.75 \mathrm{de}$ & $18.57 \mathrm{c}$ & $8.79 \mathrm{ed}$ \\
\hline $\mathrm{P}_{1} \mathrm{~S}_{3}$ & $378.35 \mathrm{e}$ & $13 \mathrm{a}$ & $14.31 \mathrm{a}$ & $0.83 \mathrm{fg}$ & $2.05 \mathrm{~cd}$ & $263.95 \mathrm{e}$ & $150.25 \mathrm{~b}$ & $18.41 \mathrm{~cd}$ & $8.87 \mathrm{cde}$ \\
\hline $\mathrm{P}_{1} \mathrm{~S}_{4}$ & $343.15 \mathrm{~g}$ & $0.35 \mathrm{c}$ & $13.30 \mathrm{~h}$ & $1.18 \mathrm{~b}$ & $\mathrm{~J} 1.26 \mathrm{k}$ & $210.64 \mathrm{~h}$ & $118.25 \mathrm{i}$ & $17.32 \mathrm{ij}$ & $8.53 \mathrm{efg}$ \\
\hline $\mathrm{P}_{2} \mathrm{~S}_{1}$ & $388.86 \mathrm{~cd}$ & $12.75 \mathrm{a}$ & $13.29 \mathrm{~h}$ & 0.86 efg & $2.78 \mathrm{a}$ & $288.88 \mathrm{c}$ & $142.75 \mathrm{cde}$ & $19.26 \mathrm{a}$ & $9.71 \mathrm{a}$ \\
\hline $\mathrm{P}_{2} \mathrm{~S}_{2}$ & $391.67 \mathrm{c}$ & $11.75 \mathrm{ab}$ & $13.64 \mathrm{e}$ & $0.87 \mathrm{def}$ & $1.40 \mathrm{i}$ & $234.86 \mathrm{~g}$ & $148.62 \mathrm{bc}$ & $17.94 \mathrm{fg}$ & $9.44 \mathrm{ab}$ \\
\hline $\mathrm{P}_{2} \mathrm{~S}_{3}$ & $418.57 \mathrm{a}$ & $15.5 \mathrm{a}$ & $13.72 \mathrm{~d}$ & $1.04 \mathrm{c}$ & $2.03 \mathrm{~d}$ & $320.90 \mathrm{~b}$ & $140.57 \mathrm{ef}$ & $17.73 \mathrm{gh}$ & $9.41 \mathrm{ab}$ \\
\hline $\mathrm{P}_{2} \mathrm{~S}_{4}$ & $378.44 \mathrm{de}$ & $0.18 \mathrm{c}$ & $13.55 \mathrm{ef}$ & $1.25 \mathrm{a}$ & $1.3 \mathrm{j}$ & $315.91 \mathrm{~b}$ & $134.76 \mathrm{fg}$ & $18.49 \mathrm{~cd}$ & $9.21 \mathrm{bc}$ \\
\hline $\mathrm{P}_{3} \mathrm{~S}_{1}$ & $375.28 \mathrm{e}$ & $11 \mathrm{~b}$ & $13.85 \mathrm{c}$ & $0.82 \mathrm{fg}$ & $2.24 b$ & $277.42 \mathrm{~d}$ & $130.48 \mathrm{gh}$ & $18.32 \mathrm{de}$ & $8.55 \mathrm{efg}$ \\
\hline $\mathrm{P}_{3} \mathrm{~S}_{2}$ & 384.16 cde & $15.75 \mathrm{a}$ & $14.03 \mathrm{~b}$ & $0.69 \mathrm{~h}$ & $1.97 \mathrm{e}$ & $259.67 \mathrm{e}$ & $157.6 \mathrm{a}$ & $17.51 \mathrm{hi}$ & $8.55 \mathrm{efg}$ \\
\hline $\mathrm{P}_{3} \mathrm{~S}_{3}$ & $389.5 \mathrm{c}$ & $17 a$ & $13.95 \mathrm{bc}$ & $0.81 \mathrm{~g}$ & $1.47 \mathrm{~h}$ & $249.46 \mathrm{f}$ & $141.39 \mathrm{ed}$ & $18.95 \mathrm{~b}$ & $9.45 \mathrm{ab}$ \\
\hline $\mathrm{P}_{3} \mathrm{~S}_{4}$ & $364.26 \mathrm{f}$ & $10.75 \mathrm{~b}$ & $13.50 \mathrm{f}$ & $1.14 \mathrm{~b}$ & 1.121 & $216.67 \mathrm{~h}$ & $126.45 \mathrm{~h}$ & $16.99 \mathrm{k}$ & $8.90 \mathrm{cde}$ \\
\hline $\mathrm{P}_{4} \mathrm{~S}_{1}$ & $364.14 \mathrm{f}$ & $0.25 \mathrm{c}$ & $13.22 \mathrm{hi}$ & $1.05 \mathrm{c}$ & $1.77 \mathrm{~F}$ & $290.49 \mathrm{c}$ & $118.72 \mathrm{i}$ & $18.16 \mathrm{ef}$ & $8.21 \mathrm{gh}$ \\
\hline $\mathrm{P}_{4} \mathrm{~S}_{2}$ & $381.84 \mathrm{cde}$ & $7.25 \mathrm{~b}$ & $13.98 \mathrm{bc}$ & $0.92 \mathrm{~d}$ & $2.1 \mathrm{c}$ & $275.22 \mathrm{~d}$ & $147.58 \mathrm{bcd}$ & $19.02 \mathrm{~b}$ & $9.12 \mathrm{bcd}$ \\
\hline $\mathrm{P}_{4} \mathrm{~S}_{3}$ & $360.5 \mathrm{f}$ & $12.91 \mathrm{a}$ & $13.59 \mathrm{e}$ & $0.92 \mathrm{~d}$ & $2.2 \mathrm{~b}$ & $325.43 a$ & $132.99 \mathrm{gh}$ & $17.41 \mathrm{i}$ & $7.85 \mathrm{~h}$ \\
\hline $\mathrm{P}_{4} S_{4}$ & $348.17 \mathrm{~g}$ & $0.24 \mathrm{c}$ & $13.40 \mathrm{~g}$ & $1.07 \mathrm{c}$ & 1.22 & $276.39 \mathrm{~d}$ & $118.26 \mathrm{i}$ & $17.74 \mathrm{gh}$ & $8.69 \mathrm{ef}$ \\
\hline
\end{tabular}

Mean with same letters in each column has no significant difference in $(\mathrm{p} \leq 0.05) ; \mathrm{P}_{1}=$ priming with water (control), $\mathrm{P}_{2}=$ priming with IBA at 100 ppm, $\mathrm{P}_{3}=$ priming with $\mathrm{GA}_{3}$ at $25 \mathrm{ppm}, \mathrm{P}_{4}=$ priming with ethephon at $200 \mathrm{ppm}, \mathrm{S}_{1}=$ spray with water (control), $S_{2}=$ spray with IBA at 100 ppm, $S_{3}=$ spray with $\mathrm{GA}_{3}$ at 25 ppm, $S_{4}=$ spray with ethephon at $200 \mathrm{ppm}$ 


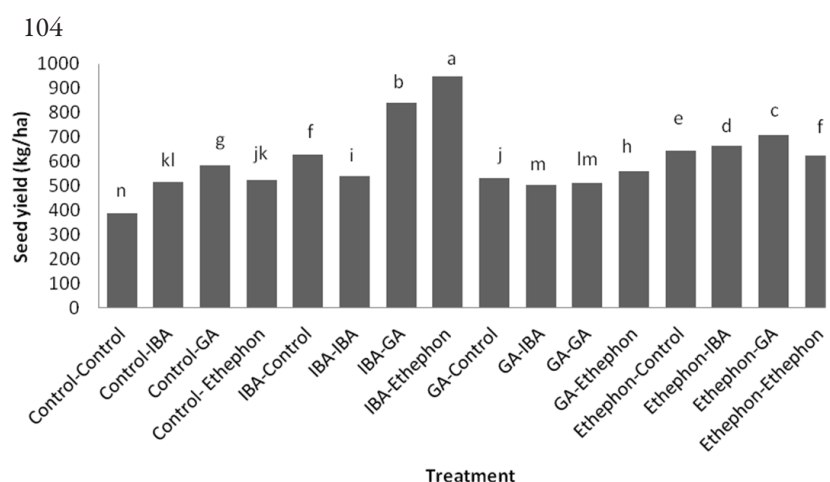

Fig. 1. Effect of PGRs on seed yield $\mathrm{kg} / \mathrm{ha}$ in medicinal pumpkin (Cucurbita pepo var. styriaca cv. 'Kaki') in farming method

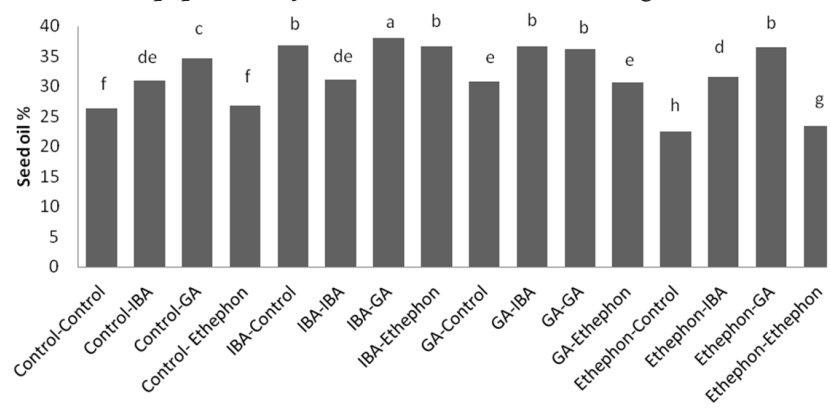

Treatment

Fig. 2. Effect of PGRs on seed $\mathrm{kg} / \mathrm{ha}$ of oil\% of medicinal pumpkin (Cucurbita pepo var. styriaca cv. 'Kaki') in farming method

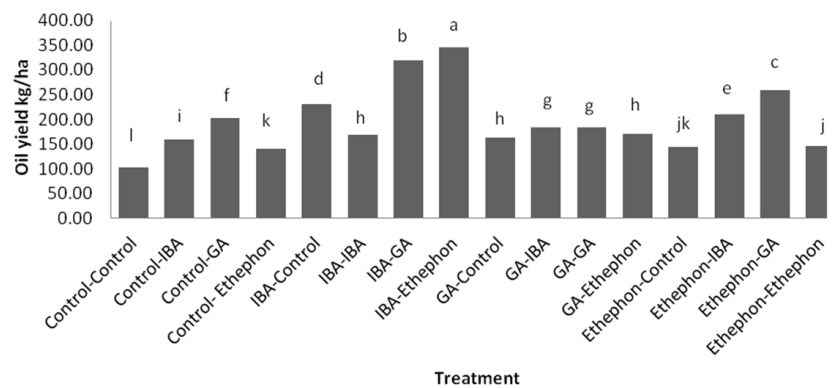

Fig. 3. Effect of PGRs on oil yield $\mathrm{kg} / \mathrm{ha}$ in medicinal pumpkin (Cucurbita pepo var. styriaca cv. 'Kaki') in farming method

effect of priming with IBA and spraying with ethephon), (Fig. 3). The result was consistent with (Jaleel et al., 2007; Pouraghdam et al., 2011; Sedghi et al., 2010). PGRs application to overcome the growth limiting factors to access the yield and maximum benefit of seed production, and proved exogenous foliar application of growth regulators stimulate flowering, pollination, fertilization and seed setting to get maximum seed yield.

\section{Experiment 2 (trellis method)}

The result in Tab. 3 indicated the effect of PGRs on growth and yield characteristic in medicinal pumpkin.

\section{Morphological traits}

$\mathrm{GA}_{3}$ had more effective influence on growth characteristics compared to the other treatment. The highest Leaf area $(391.18) \mathrm{cm}^{2}$ was recorded at $\mathrm{P}_{1} \mathrm{~S}_{3}$ (combined effect of priming with control and spraying with $\mathrm{GA}_{3}$ ) treatment.
The highest DM\% of plant (14.66\%) was measured in $\mathrm{P}_{1} \mathrm{~S}_{3}$ (combined effect of priming with control and spraying with $\mathrm{GA}_{3}$ ). Gehan et al. (2001) reported $\mathrm{GA}_{3}$ and IAA increased plant height and \%DM in balanites aegyptiaca. Yaxley et al. (2001) reported that seed priming by $\mathrm{GA}_{3}$ increased stem elongation, leaf expansion, and root growth on pea. In trellis method, considering the limit in space, plants which had rapid growth in primary stage can affect other plant by shading. $\mathrm{GA}_{3}$ at an early stage increased the plant growth and then plant which treated by $\mathrm{GA}_{3}$ had a great leaf area and level of light absorption that caused increasing in yield and DM\%.

\section{Floral traits}

The data showed that ethephon was more effective sex expression on cucurbita plants. Spray ethephon significantly reduced the sex ratio and $\mathrm{GA}_{3}$ treatment (combined effect of priming with $\mathrm{GA}_{3}$ and spraying with $\mathrm{GA}_{3}$ ) significantly enhanced sex ratio this result confirmed by (Yongan et al. (2002) on summer squash, Thappa et al. (2011) on cucumber.

\section{Yield components}

Data in Tab. 3 showed the yield Components. One of the main problems in Cucurbita pepo is low fruit set. It seems that Ethephon enhanced fruit set by increasing female flower. The number of fruit/plant enhanced by Ethephon treatment and maximized by $\mathrm{P}_{1} \mathrm{~S}_{4}$ (combined effect of priming with control and spraying with Ethephon) to 1.29. The application of $\mathrm{GA}_{3}$ was more effective on fresh weight of fruit. Fresh weight of fruit was maximized by $\mathrm{P}_{3} \mathrm{~S}_{1}$ (combined effect of priming with $\mathrm{GA}_{3}$ and spraying with control). Maximum seed/fruits (262.6) was observed in $\mathrm{P}_{1} \mathrm{~S}_{3}$ (combined effect of priming with control and spraying with $\mathrm{GA}_{3}$ ). One hundred seed weight was affected by GA treatment $P_{1} S_{3}$ (combined effect of priming with control and spraying with $\mathrm{GA}_{3}$ ) and had significant effect with the other treatment. Seed length was maximized by $\mathrm{P}_{3} \mathrm{~S}_{2}$ (combined effect of priming with $\mathrm{GA}_{3}$ and spraying with IBA) to $(20.01 \mathrm{~mm})$ and seed width was maximized by $\mathrm{P}_{3} \mathrm{~S}_{3}$ (combined effect of priming with $\mathrm{GA}_{3}$ and spraying with $\left.\mathrm{GA}_{3}\right)$ to $(10.04 \mathrm{~mm})$.

\section{Total seed yield (kg/ha), seed oil percent and total seed oil $\mathrm{kg} / \mathrm{ha}$ \\ The maximum total seed yield $(1686.21 \mathrm{~kg} / \mathrm{ha})$ was} found in $\mathrm{P}_{1} S_{3}$ (combined effect of priming with control and spraying with $\mathrm{GA}_{3}$ ) Vegetative growth in trellis method was limited by low space availability. GA treated increased primary growth and plant. In competition with the other, it could enhance seed yield by increasing photosynthesis. It seems that $\mathrm{P}_{3} \mathrm{~S}_{3}$ (combined effect of priming and spray with $\mathrm{GA}_{3}$ ) which decreases female flower and number of fruit/pant too could not enhance seed yield as $\mathrm{P}_{1} \mathrm{~S}_{3}$. This result is consistent with the results of Musabber et al. (2010), Asrey et al. (2001) in their study. The seed oil 
Tab. 3. Effect of PGRs on growth and yield characteristics of (Cucurbita pepo var. styriaca cv. 'Kaki') in trellis method

\begin{tabular}{|c|c|c|c|c|c|c|c|c|c|}
\hline Treatment & $\begin{array}{c}\text { Leaf area } \\
\mathrm{cm}^{2}\end{array}$ & $\begin{array}{c}\text { Sex ratio } \\
\text { male/female }\end{array}$ & $\begin{array}{l}\text { DM of } \\
\text { vine } \%\end{array}$ & $\begin{array}{l}\text { Number of } \\
\text { fruit per plant }\end{array}$ & $\begin{array}{l}\text { Fresh weight } \\
\text { of fruit }(\mathrm{kg})\end{array}$ & $\begin{array}{c}\text { Number of } \\
\text { seed per fruit }\end{array}$ & $\begin{array}{l}1000 \text { Seed } \\
\text { weight }(\mathrm{g})\end{array}$ & $\begin{array}{l}\text { Length of } \\
\text { seed }(\mathrm{mm})\end{array}$ & $\begin{array}{l}\text { Width of } \\
\text { seed }(\mathrm{mm})\end{array}$ \\
\hline $\mathrm{P}_{1} \mathrm{~S}_{1}$ & 348.50 ef & $10.50 \mathrm{~b}$ & $13.07 \mathrm{i}$ & $0.70 \mathrm{e}$ & $1.71 \mathrm{e}$ & $115.34 \mathrm{i}$ & $114.96 \mathrm{ced}$ & $16.18 n$ & $7.98 \mathrm{~h}$ \\
\hline $\mathrm{P}_{1} \mathrm{~S}_{2}$ & $364 d$ & $8.92 \mathrm{~b}$ & $14.38 \mathrm{~b}$ & $0.64 \mathrm{f}$ & $1.69 \mathrm{e}$ & $227.8 \mathrm{~cd}$ & $114.7 \mathrm{cde}$ & $16.40 \mathrm{~m}$ & $8.68 \mathrm{~g}$ \\
\hline $\mathrm{P}_{1} \mathrm{~S}_{3}$ & $391.18 \mathrm{a}$ & $13.75 \mathrm{ab}$ & $14.66 \mathrm{a}$ & $1.05 \mathrm{~b}$ & $2.07 \mathrm{~b}$ & $262.6 \mathrm{a}$ & $132.21 \mathrm{a}$ & $17.93 \mathrm{f}$ & $9.09 \mathrm{~cd}$ \\
\hline $\mathrm{P}_{1} \mathrm{~S}_{4}$ & $351.20 \mathrm{ef}$ & $0.35 \mathrm{c}$ & $13.43 \mathrm{~h}$ & $1.29 \mathrm{a}$ & $1.78 \mathrm{~d}$ & $134.8 \mathrm{~h}$ & $111.79 \mathrm{defg}$ & $17.84 \mathrm{~g}$ & $8.64 \mathrm{~g}$ \\
\hline $\mathrm{P}_{2} \mathrm{~S}_{1}$ & $345.36 \mathrm{f}$ & $13 \mathrm{ab}$ & $13.56 \mathrm{~g}$ & $0.80 \mathrm{~d}$ & $1.52 \mathrm{f}$ & $218.1 \mathrm{~d}$ & $119.79 \mathrm{bc}$ & $19.04 \mathrm{~b}$ & $9.47 \mathrm{bc}$ \\
\hline $\mathrm{P}_{2} \mathrm{~S}_{2}$ & $362.13 \mathrm{~d}$ & $9.88 \mathrm{~b}$ & $13.69 \mathrm{ef}$ & $0.63 \mathrm{f}$ & $1.45 \mathrm{gh}$ & $210.24 \mathrm{df}$ & $117.12 \mathrm{bcd}$ & $17.25 \mathrm{k}$ & $9.32 \mathrm{bcd}$ \\
\hline $\mathrm{P}_{2} \mathrm{~S}_{3}$ & $376.88 \mathrm{c}$ & $16.50 \mathrm{a}$ & $13.76 \mathrm{e}$ & $0.58 \mathrm{~g}$ & $1.48 \mathrm{~g}$ & $206.5 \mathrm{f}$ & $112.77 \mathrm{def}$ & $17.54 \mathrm{i}$ & $8.99 \mathrm{ef}$ \\
\hline $\mathrm{P}_{2} \mathrm{~S}_{4}$ & $355.4 \mathrm{e}$ & $0.19 \mathrm{c}$ & $13.65 \mathrm{f}$ & $0.61 \mathrm{fg}$ & $0.98 \mathrm{k}$ & $226.5 \mathrm{~cd}$ & $107.77 \mathrm{fgh}$ & $18.31 \mathrm{c}$ & $10.04 \mathrm{a}$ \\
\hline $\mathrm{P}_{3} \mathrm{~S}_{1}$ & $370.64 \mathrm{~cd}$ & $13.25 \mathrm{ab}$ & $13.94 \mathrm{~d}$ & $0.64 \mathrm{f}$ & $2.18 \mathrm{a}$ & $212.0 \mathrm{df}$ & 107 ghi & $17.49 j$ & $9.50 \mathrm{bc}$ \\
\hline $\mathrm{P}_{3} \mathrm{~S}_{2}$ & $364.21 \mathrm{~d}$ & $16.25 \mathrm{a}$ & $14.18 \mathrm{c}$ & $0.51 \mathrm{~h}$ & $1.83 \mathrm{c}$ & $226.1 \mathrm{~cd}$ & $121.75 b$ & $20.01 \mathrm{a}$ & $9.58 \mathrm{~b}$ \\
\hline $\mathrm{P}_{3} \mathrm{~S}_{3}$ & $380.23 b$ & $19 a$ & $14.06 \mathrm{~d}$ & $0.72 \mathrm{e}$ & $1.82 \mathrm{c}$ & $241.34 \mathrm{~b}$ & $121.3 \mathrm{~b}$ & $18.15 \mathrm{e}$ & $9.29 \mathrm{~cd}$ \\
\hline $\mathrm{P}_{3} \mathrm{~S}_{4}$ & $360.15 \mathrm{de}$ & $0.24 \mathrm{c}$ & $13.67 \mathrm{ef}$ & $0.64 \mathrm{f}$ & $1.13 \mathrm{j}$ & $197.97 \mathrm{~g}$ & $107.3 \mathrm{fghi}$ & 16.511 & $8.60 \mathrm{~g}$ \\
\hline $\mathrm{P}_{4} \mathrm{~S}_{1}$ & $345.80 \mathrm{f}$ & $10 \mathrm{~b}$ & $13.44 \mathrm{~h}$ & $0.73 \mathrm{e}$ & $1.43 \mathrm{~h}$ & $200.4 \mathrm{~g}$ & $120.75 b$ & $15.75 p$ & $7.92 \mathrm{~h}$ \\
\hline $\mathrm{P}_{4} \mathrm{~S}_{2}$ & $355.18 \mathrm{e}$ & $4.79 \mathrm{c}$ & $13.94 \mathrm{~d}$ & $0.96 \mathrm{c}$ & $1.85 \mathrm{c}$ & $232.14 \mathrm{c}$ & $120.75 b$ & $17.56 \mathrm{~h}$ & $8.82 \mathrm{fg}$ \\
\hline $\mathrm{P}_{4} \mathrm{~S}_{3}$ & $360.63 \mathrm{de}$ & $11.88 \mathrm{~b}$ & 13.67 ef & $0.62 \mathrm{fg}$ & $1.33 \mathrm{i}$ & $215.8 \mathrm{~d}$ & $110.3 \mathrm{efgh}$ & $15.87 \mathrm{o}$ & $8.12 \mathrm{~h}$ \\
\hline $\mathrm{P}_{4} \mathrm{~S}_{4}$ & $345.36 \mathrm{f}$ & $0.16 \mathrm{c}$ & $13.42 \mathrm{~h}$ & $0.96 \mathrm{~d}$ & $1.34 \mathrm{i}$ & $200.5 \mathrm{~g}$ & $105.42 \mathrm{hi}$ & $18.21 \mathrm{~d}$ & $9.16 \mathrm{de}$ \\
\hline
\end{tabular}

Mean with same letters in each column has no significant difference in $(\mathrm{p} \leq 0.05) ; \mathrm{P}_{1}=$ priming with water (control), $\mathrm{P}_{2}=$ priming with IBA at 100 ppm, $\mathrm{P}_{3}=$ priming with $\mathrm{GA}_{3}$ at $25 \mathrm{ppm}, \mathrm{P}_{4}=$ priming with ethephon at $200 \mathrm{ppm}$. $\mathrm{S}_{1}=$ spray with water (control), $\mathrm{S}_{2}=$ spray with IBA at 100 ppm, $S_{3}=$ spray with $\mathrm{GA} \mathrm{A}_{3}$ at $25 \mathrm{ppm}, \mathrm{S}_{4}=$ spray with ethephon at $200 \mathrm{ppm}$.

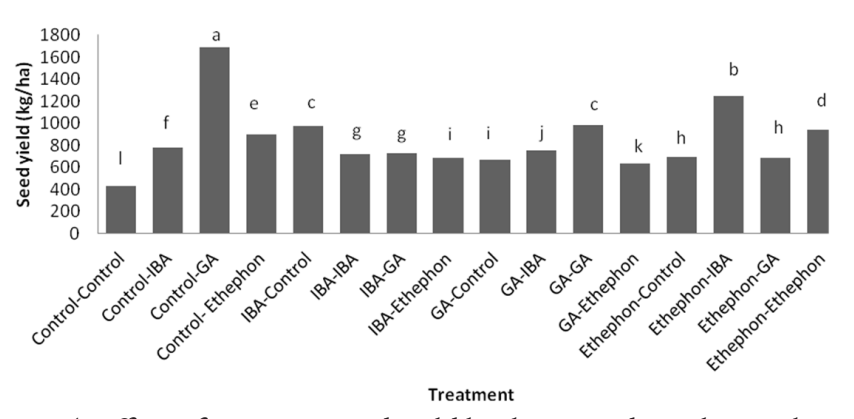

Fig. 4. Effect of PGRs on seed yield $\mathrm{kg} / \mathrm{ha}$ in medicinal pumpkin (Cucurbita pepo var. styriaca cv. 'Kaki') in trellis method

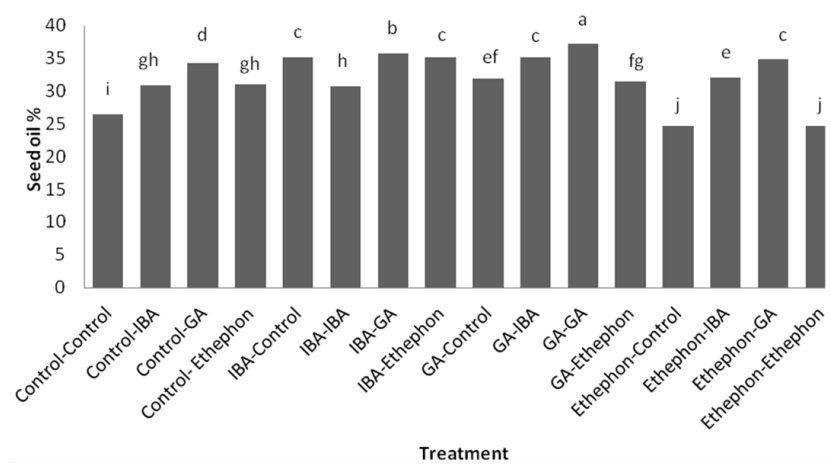

Fig. 5. Effect of PGRs on oil \% of medicinal pumpkin (Cucurbita pepo var. styriaca cv. 'Kaki') in trellis method

$\%$ was directly affected by PGRs application. The result indicated that foliar application of $\mathrm{P}_{2} \mathrm{~S}_{3}$ (combined effect of priming with $\mathrm{GA}_{3}$ and spraying with $\mathrm{GA}_{3}$ ) treatment enhanced seed oils\% (37.175\%) significantly compared to the other treatment (Fig. 5), and oil yield to (577.46) was maximized by $\mathrm{P}_{1} \mathrm{~S}_{3}$ (combined effect of priming with $\mathrm{GA}_{3}$ and spraying with $\mathrm{GA}_{3}$ ), (Fig. 6). Many researchers have

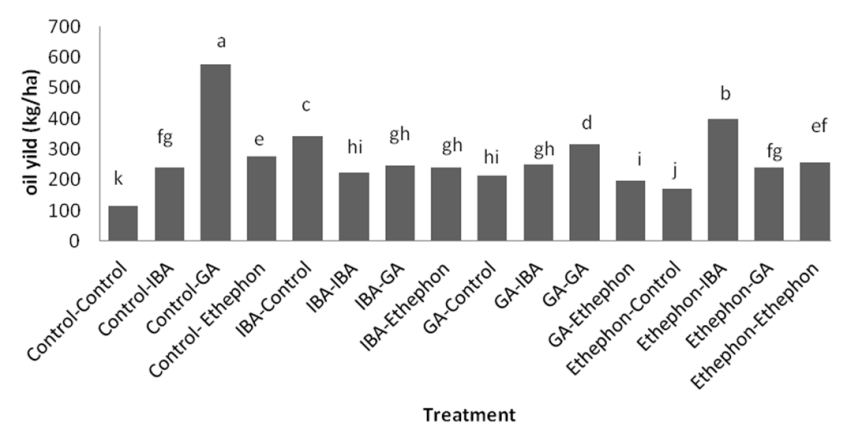

Fig. 6. Effect of PGRs on oil yield $\mathrm{kg} / \mathrm{h}$ a of medicinal pumpkin (Cucurbita pepo var. styriaca cv. 'Kaki') in trellis method

proven that gibberellin is associated in increasing the protein and vitamin and oil of grain (Akter et al., 2007; Manjit Singh et al., 2011; Sedghi et al., 2010). GA effectively increased yield and oil in Ocimum basilicum (Shukla and Farooqi, 1990).

\section{Comparison of two experiments}

The result indicated that trellis method was an effective method of planting in medicinal pumpkin culture compared to farming method. Present data showed the maximum yield in trellis method obtained in $\mathrm{P}_{1} \mathrm{~S}_{3}(1686.21 \mathrm{~kg} /$ ha) that was significantly higher than maximum yield in farming method at $\mathrm{P}_{2} \mathrm{~S}_{4}(946.73 \mathrm{~kg} / \mathrm{ha})$ treatment. Seed yield $\mathrm{kg} / \mathrm{ha}$ was duplicated in trellis method by optimum use of available space. Minimum yield in both planting methods was observed in control treatment but in control treatment in trellis method seed yield $\mathrm{kg} / \mathrm{ha}$ increased by $17 \%$ compared to the farming method control treatment. Ridge gourd (Luffa acutangula Roxb.) and sponge gourd (Luffa cylindrica Roem.) are in trellis method which get 
106

higher yield. (Saimbhi, 1993). Fruit yield of muskmelon enhanced significantly in trellis method, and this method reduced plant to plant spacing to $30 \mathrm{~cm}$ (Singh et al., 1982). Hilli et al. (2009) reported that trellis method enhanced yield in ridge gourd (Luffa acutangula L. Roxb) by $30-35 \%$ compared to farming method.

\section{Conclusions}

Due to the limit of farm land to achieve maximum yield, an appropriate culture system and optimum use of area under planting is necessary to get higher performance with the optimum use of available space. The effect of PGRs in various Vegetative and Generative processes in plants is well known. Growth regulators affect seed germination, vegetative growth, flower induction, fruit set, seed development, fruit ripening and yield. PGRs may increase root activity and plasticity of cell wall to provide greater absorption of water and nutrients and cause enhancement in growth and yield. In generally growth regulators have different effects on seed yield and oil\% in medicinal pumpkin. As regards the main gold of medicinal pumpkin planting is Access to height amount of oil GA $\mathrm{G}_{3}$ can improve the seed yield and oil\% effectively. Thus, given the obtained data, the use of $\mathrm{GA}_{3}$ is recommended and trellis method could lead these crops manufacturers to access more yield.

\section{References}

Akter A, Ali E, Ilam MMZ, Karam R, Razzaque AHM (2007). Effect of $\mathrm{GA}_{3}$ on growth and yield of mustard. Int J Sustain Crop Prod 2(2):16-20.

Al-Khassawaneh NM, Karam NS, Shibli RA (2006). Growth and flowering of black iris (Iris nigricans Dinsm.) following treatment with plant growth regulators. Sci Hortic 107:187193.

Asrey R, Singh GN, Shukla HS, Singh R (2001). Effect of seed soaking with Gibberellic acid on growth and fruiting of muskmelon (Cucumis melo L.). Haryana J Hort Sci 30(34):277-278.

Birader G, Navalagatti CM (2008). Effect of olant growth regulators on physiology and quality in bittergourd (Momordica charantia). MSc thesis, university of agricultural sciences, Dharwad.

Bombardelli E, Morazzoni P (1997). Cucurbita pepo L. Titoterapia Vol. LXVIII(4):291-302.

Brantley BB, Warreng F (1960). Sex expression and growth in muskmelon. J Plant Physiol 1428:741-745.

Chauhan JS, Tomar YK, Badoni A, Indrakumar N, Seema S, Debarati A (2010). Morphology, germination and early seedling growth in Phaseolus mungo L. with reference to the influence of various plant growth substances. J Am Sci 6(1):34-41.

Chauhan JS, Tomar YK, Indrakumar N, Seema S, Debarati A (2009). Effect of growth hormones on seed germination and seedling growth of black gram and horse gram. J Am Sci 5(5):79-84.

Desai UT, SHinde HJ, Choudhari SM, Kale PN (1994). Effect of growth regulators on quality of watermelon fruits. Ind J Hortic 51:285-287.

Dostogir H, Abdul Karim M, Habibur Rahman Pramanik M, Syedur Rahman AM (2006). Effect of gibberellic acid $\left(\mathrm{GA}_{3}\right)$ on flowering and fruit development of bittergourd (Momordica charantia L.). Intl J Bot 2:329-332.

Emongor V (2007). Gibberellic acid (GA) influence on vegetative growth, nodulation and yield of cowpea (Vigna unguiculata (L) Walp. J Agron 6:509-517.

Gad AA, Alsadon AA, Wahdan HM (1993). Sex expression and yield response of summer squash to ethrel. Ann Agric Sci, Ani Shams Univ Cairo 38:251-259.

Gedam VM, Patil RB, Suryawanshi VB, Mate SN (1998). Effect of plant growth regulators and boron on flowering, fruiting and seed yield in bitter gourd. Seed Res 26(1):97-100.

Gehan GM, Abou Ahmad MF (2011). Effect of gibberllic acid and indole 3-acetic on improving growth and yield accumulation of phytochemical composition in balanites aegyptica plants. Am J Pant Physiol 6(1):36-43.

Hilli JS, Vyakaranahal BS (2005). Studies on seed production and post-harvest techniques in ridge gourd (Luffa acutangula L. Roxb). Ph. D. Thesis, University of Agricultural Sciences, Dharwad.

Hilli JS, Vyakaranahal BS, Biradar DP, Hunje R (2009). Influence of method of trailing and fertilizer levels on seed yield of ridgegourd (Luffa acutangula L. Roxb). Karnataka J Agric Sci 22: 47-52.

Jaleel CA, Gopi R, Manivannan P, Sankar B, Kishorekumar A, Panneerselvam R (2007). Antioxidant potentials and ajmalicine accumulation in Catharanthus roseus after treatment with gibberellic acid. Colloids and Surfaces B: Biointerfaces 60:195-200.

Jamil M, Rha ES (2007). Gibberllic acid ( $\left.\mathrm{GA}_{3}\right)$ enhance seed water uptake germination and early seedling growth in sugar beet under salt stress. Pak J Biol Sci 10(4):654-658.

Korzeniewska A, Niemirowiez SK (1993). Effect of ethrel on fruit and seed related characters in four inbred lines of Cucurbita maxima duch. Gatenbauwissenschaff 58:266271.

Manjit Singh DK, Rana J, Rawat MS, Rawat SS (2011). Effect of $\mathrm{GA}_{3}$ and kinetin on growth, yield and quality of sprouting broccoli (Brassica oleracea var. italica). J Hortic For 3(9):282285.

Marbhal SK, Musmade AM, Kashi NV, Kamble MS, Kamthe PV (2005). Effect of growth regulators and picking sequence on seed yield of bittergourd. Haryana J Hort Sci 34(3-4):323326.

Ntui VO, Uyoh EA, Udensi O, Enok LN (2007). Response of pumpkin (Cucurbita ficifolia L.) to some growth regulators. J Food, Agricult Environ5(2):211-214. 
Part L, Botti C, Fichet T (2008). Effect of plant growth regulators on floral differentiation and seed production in Jojoba (Simmondsia chinensis (Link) Schneider). Indus Crops Products 27:44-49.

Pouraghdam MB, Hajisamadi AslB, Khalighi A (2010). Gibberellic acid foliar application influences growth, volatile oil and some physiological characteristics of lavender (Lavandula officinalis Chaix). Rom Biotechnol Lett 16:6322-6327.

Sedghi M, Nemati A, Khandan Bejandi T, Namvar A (2010). The effect of growth regulators on grain biophysicochemical characteristics and yield in medicinal pumpkin (Cucurbita pepo L.) Iran J Med Aromatic Plants 26:41-48.

Shukla A, Farooqi AH (1990). Utilization of plant growth regulators in aromatic plant production. Curr Res Med Arom Plants 12:152-157.

Sidhu AS, Pandita ML, Arora SK (1981). Effect of growth regulators on growth, sex expression and yield in squashmelon. Haryana Agric Univ J Res 11(4):489.

Singh B, Mangal JL, Pandita ML (1982). Effect of pruning, spacing and fertilizer levels on flowering, fruiting, yield and quality of muskmelon. Haryana Agric Univ J Res 12:64-68.
107

Thappa M, Kumar S, Rafiq R (2011). Influence of plant growth regulators on morphological, floral and yield traits of cucumber (Cucumis sativus L.). Kasetsart J (Nat Sci) 45:177-188.

Vadiger BG, Madalageri BB, Sheelavantar MN (2001). Effect of ethrel and gibberellic acid on yield and quality of two cucumber varieties. Karnataka J Agric Sci 14:727-730.

Vwioko ED, Longe MU (2009). Auxin and gibberellin effects on growth and fruit size in Lagenaria siceraria (Molina) Standley. Biosci Res Communic 21:263-272.

Yamasaki S, Fujii N, Takahashi H (2003). Characterization of ethylene effects on sex determination in cucumber plants. Sex Plant Reprod 16:103-111.

Yongan C, Bingkui Z, Enhui Z, Zunlian Z (2002). Control of sex expression in summer squash (Cucurbita pepo L.). Cucurbit Genetics Cooper Report 25:51-53. 